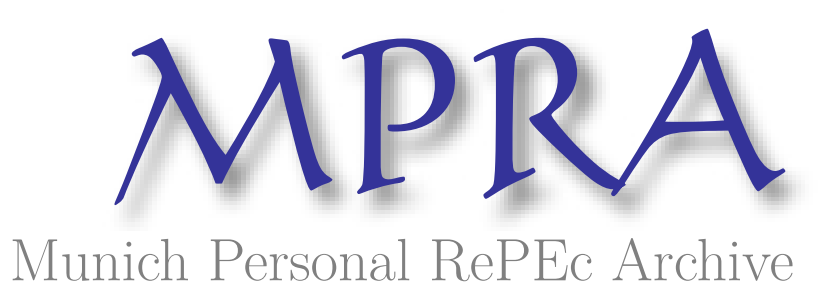

\title{
Understanding corporate social responsibility of Commercial Banks of Nepal
}

Bista, Raghu

2 December 2017

Online at https://mpra.ub.uni-muenchen.de/100109/

MPRA Paper No. 100109, posted 09 May 2020 13:01 UTC 
UNDERSTANDING CORPORATE SOCIAL RESPONSIBILITY OF COMMERCIAL BANKS: EVIDENCE OF DEVELOPING COUNTRIES, NEPAL

\author{
Dr. Raghu Bir Bista \\ Assistant Professor, Department of Economics, PMC, Tribhuvan University \\ Post Box No: 9137, Kathmandu, Nepal \\ E-mail: bistanepal@gmail.com
}

\begin{abstract}
:
Corporate Social Responsibility (CSR) is emerging debatable hot issue in the globalization era, when role of the Commercial Banks has been supporting to development of industry, trade and market. A large number of the Commercial Banks have been providing financial services by expanding competitive financial markets and impressive profits. However, CSR is still debate. This issue was examined through explorative and descriptive method based on secondary and primary data.

The study finds CSR as voluntarily social responsibility of the Commercial Banks. It is least priority of the Commercial Banks. Its size is least. Its trend is irregular and discontinuous. Therefore, almost stakeholders are unsatisfied and opines to its need mandatory for its positive impacts.
\end{abstract}

Key Words: CSR, Bank, Value, ethical Business and Social Responsibility etc. 


\section{INTRODUCTION}

This paper examines Corporate Social Responsibility (CSR)'s nature and practices of the commercial banks in Nepal, where the corporate sector has been expansionary in all sectors after Nepal initiated the economic reform 1992 to liberalize all sectors of the economy to the corporate investment, except few sensitive areas (communication and security)(Bista, 2004, Bista, 2005, Bista, 2005, Bista, 2008, Bista, 2009, Bista, 2011, Bista, 2016, \& MoF, 2017). Its good result occurs in the commercial banking sector in terms of number, services and investment. Bista (2008), Bista (2011), Bista (2016), NRB (2017) and MoF (2017) report 28 Commercial Banks and 48 Development Banks. In 1990s, its numbers were only six. Until 2017, its growth rate is 400 times in the Commercial Banks and 800 times in Development Banks. Their net profit figures are very impressive in the top competitive financial market. At some extent, these banks have initiated social responsibility, although the industrial policy has made it voluntarily, unlike India and USA where corporate social responsibility is mandatory. In India, the corporate sector has to spend at least 2 percent of their annual profit in the society as corporate social responsibility. In USA, it is also1 percent legal and ethical mandatory. Despite its voluntary nature, the well aware consumer expects their Commercial Bank's significant contribution to the society as their social responsibility in accordance with international norms and values of the corporate governance. There are few handful literatures (Bista 2005, Bista, 2009 \& Bista, 2011) in Nepal but almost have focused on MNC. In banking sector, there are none of literatures dealing such issue. In the context of growing CSR activities and practices of the Commercial Bank, its examination is relevant to understand in depth its nature, characters, size, trend and pattern for its promotion and development in these sectors.

This paper is organized into the following sections: Section 2: Objectives, Section 3: Literature Review, Section 4: Theoretical Framework and Section 5: Data sets and Methodology, Section 6: Results and Discussions, Section 7: Conclusions.

\section{OBJECTIVES AND METHDOLOGY}

The paper has main objective to examine CSR's nature and practices of the commercial banks in Nepal. In addition, the paper analyzes structure and trend of their CSR budget in Nepal. Further, the paper explores its size and CSR and Profit ratio and identifying their priority areas. 


\section{CSR SCENAIRO AND PRACTICE}

\subsection{Concept of CSR}

CSR is inevitable ingredients of the successful, efficient and giant corporate governance in the world. In this context, debate on CSR is still going on at the different levels in the different forums, along with mandatory or voluntarily its practices. The concept emerged in 1917, when Henry Ford initiated social responsibility in terms of value of all stakeholders' interests as well as the social welfare of employees and shareholders (Lee, 2008 and Meredith, 1999). It was not emotional. It was a business perceptive and practice to be good corporate citizen. At some extent, the company had such practices in all over the world. Immediately after the World War II, the corporate business acknowledged the need to commit some of their profits to social causes. May be its cause would be social, economic and political turmoil(1930s-1950s) and the reactionary movement of the citizens to fight against the abuse of power, corruption, tax evasion, discriminatory pricing, and lack of protection for workers and consumers and other anti-social practices by industries (Afful, 2003). Its focus was only social cause. It did not focus on the issues of workers, customer and community. Its reflection is still even in $21^{\text {st }}$ century, when they do not treat their workers, customers and their communities any better. Meanwhile, there is positive practices in which the company owners having human attitude to their workers and supported social causes, do so for religious or charitable purposes. However, distributing food and money to the poor during festivals cannot be called CSR (Afful, 2003). The Reputation Institute (2017) has listed higher CSR companies out of total companies $(170,000)$ of the world such as Lego ( $1^{\text {st }}$ Rank), Microsoft( $2^{\text {nd }}$ Rank), Google( $3^{\text {rd }}$ Rank), Walt Disney Company(4 ${ }^{\text {th }}$ Rank), BMW( $5^{\text {th }}$ Rank), Intel ( $6^{\text {th }}$ Rank), Robert Bosch( $7^{\text {th }}$ Rank), Cisco System ( $8^{\text {th }}$ Rank) and Rolls Royce( $9^{\text {th }}$ Rank). Such rating has improved their value induced sales, loyal consumer and employees more than lower rating CSR companies. Further, Sen et al. (2006) noted the growth of CSR activities and its influence on sales growth and the employment and investment. Carmeli (2005) mentioned it as a sustainable competitive advantage. Therefore, it has become ingredients of corporate governance for competitive advantage.

Academic perspective attempted on CSR in 1932, when Dodd (1932) and Berle (1932)

published their article on "For Whom Are Corporate Managers Trustees?" in a Harvard Law Review. In 1953, Bowen published a book, Social Responsibilities of the Businessman 
focusing on the relationship of corporation with society and need of business ethics (Carroll, 1979). In 1970, Milton Friedman (1970) continued this debate through his article on "The Social Responsibility of Business Is to Increase Its Profits," in the New York Times Magazine. Thus, CSR has received public and academic attention for social interest. Such evolution of academic perspective has contributed its modern concept. The literatures (Carroll, 1999; Engardio et al. 2007; Hart, 1995; Holmes and Watts, 2000; McWillams and Siegel, 2001; Nicolau, 2008; Tsoutsoura, 2004) mention CSR as the activities making companies good citizens who contribute to society's welfare beyond their own self-interests. In addition, Elhauge (2005) explains CSR as sacrificing profits in the social interest. In simple, it is social work of the corporate sector in the society. Similarly, Graff Ziven and Small (2005), Portney (2005) and Reinhardt (2005) in their papers have offered similar arguments consistently. If we examine it, we can find that it is normative nature and general statement in which the corporate sector binds to contribute in the society through using profit share but it must be in accordance with the social interest. It means not specifically whatever social goods desired by the society, which may be either environment or infrastructure or social sectors (health or education or sanitation).

\subsection{CSR: Mandatory or Voluntarily}

Some literatures (Griffin, 1998; Afful, 2003; Kootz and Weihrich, 1990 and Kreitner, 1999) have discussed whether CSR is mandatory and voluntarily. Griffin (1998) defines it as the set of obligations an organization has to protect and enhance the societal context in which it functions. Social responsibilities of business mean responsibilities of business towards customers, workers, shareholders and the community (Afful, 2003). The government of India (2017) mentioned it as mandatory in the Industrial Policy. Koontz and Weihrich (1990) and Kreitner (1999) argue in the similar way in their papers. EU (2001) focuses more on the integration of social and environmental interest. However, Bista (2005), Bista (2008), Bista (2011), Bista (2011), Bista (2016) \& the government of Nepal (2017) explains it voluntarily by giving freedom to the corporate sector. Thus, CSR is in both mandatory and voluntarily in accordance with the country's perspective and policy on the corporate governance. 


\subsection{CSR: its components Pyramid}

Sriram and Achick (2003) conceptualize categorically on CSR issue with the statement, "Conceptually, CSR is a bridge that links corporate and social interests in two ways. First, the firm is presumed to have other goal that it strives to achieve in addition to its shareholder wealth maximization goals. Second, groups other than stockholders (e.g. employees, customers,

Figure 1: The Pyramid of CSR

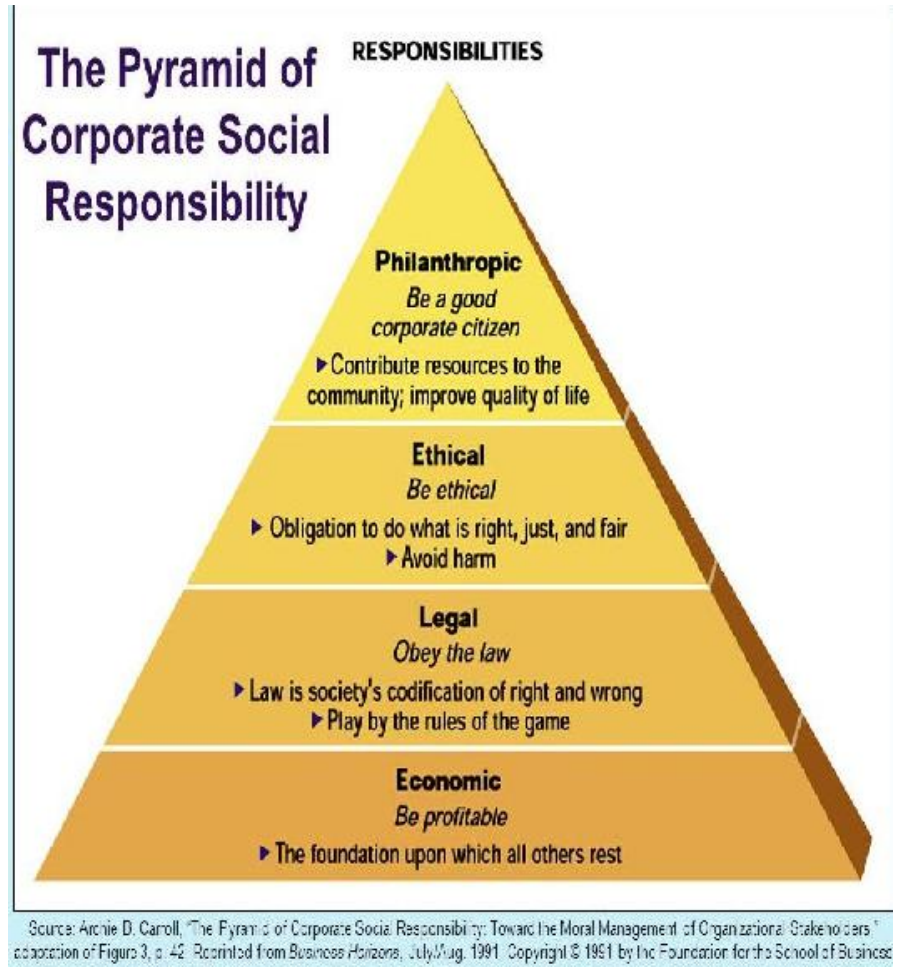

and community) are perceived to have a vested interest in the consequences of firm's actions." We can conclude CSR as investment on business and social interest as well as environmental interest. Schwartz and Caroll(2003) explained its three components: economic, legal and ethical in their conceptual framework.

CSR practices in the Corporate Governance

CSR practices in the Corporate Governance are heterogeneous in the world. Its determinant factors are

generally legal provision, ethical obligation and value creation as shown in the pyramid of CSR. European Countries and USA have clear and comprehensive corporate laws about CSR that is the corporate bodies sacrifice their profit for their public social welfare and business expansion.

For example, every US state recognizes the right of businesses to make charitable contributions. Seven states allow charitable donations regardless of corporate benefit, and nineteen other states allow donations that benefit the business or advance the public welfare (Choper, Coffee, and Gilson, 2004). Statutes in the remaining 24 states (including Delaware) include similar language, but without legal clarification about whether donations are permitted, when they do not benefit the firm (Donohue, 2005). Therefore, CSR is legally mandatory to the corporate body. Similar practices occur in European countries, where the stakeholder's participation is 
endorsed in CSR practices. Europeans have sought to incorporate CSR into their investment climate, both at the institutional and individual level (Sutton, 2004), and in strong social democracies, such as Germany and France, stakeholders (particularly employees) have much stronger legal positions than in the United States (Roe, 2000). Corporations in Europe and Asia are also more likely to have a few large shareholders, who may take social responsibilities seriously, particularly those towards employees (Roe, 2000). Further, European countries have focused more on the inclusion of stakeholders for CSR's transparency and effectiveness.

CSR is emerging issue in developing countries, where subsistence agriculture dominates to Industrial sector and traditional business patterns led to the corporate sector. It is new experience to the corporate sector. After the liberalization to FDI, MNC has brought such concept and practices at some extent in accordance with their mother countries norms, values and systems. Its practices seem to be contrast and dark more than developed countries. Literatures of CSR in developing countries (Human Development Index (HDI), Transparency International and Global Integrity) mentions poor CSR because of the absence of CSR provision in the corporate law. May be the government has not such way of thinking in the policy formulation. May be it is distracted by the lack of good governance, political stability, democratic issue, corruption and supremacy of law. Therefore, the lack of CSR provisions in the corporate law is a big issue. In this critical context, Multinational Company (MNC) has violated their mother country's CSR norms, values and system, except making a profit by ignoring all these issues. Therefore, CSR practices of MNC are unexpectedly poor and critical. Therefore, additional CSR of MNC is only a dream to the government and the people.

\subsection{CSR practices in Nepal}

CSR is not new issue in Nepalese society, when we observe the evidence. In Medieval and Modern Period, CSR was a major ingredient of Nepalese society and its behavior. Its practice was individual level of Merchant and Businessman to get business as well as good will value. It was not profit based. In general, such social responsibility was philanthropy nature and pattern in which road, tap, schools, health post, public place, open place, the establishment of temples and other infrastructure having social and religious value and concern (Bista, 2016). It was religious obligation, except business obligation. Its impact was good but was limited. Since 1990, modern CSR has been appearing in the corporate sector, although the corporate law has not mandatory provision of CSR, like as India has. CSR relates to corporate sector as business 
ethics and responsibility. Nepal (2006) in CSR report of FNCCI (2006) perceives CSR as the commitment from business enterprise towards sustainable economic development, creating good working environment for employee/ their families and local community / society welfare at large to improve the quality of life. Furthermore, the employees should be considered as business' best assets and ambassadors. Employee, shareholders, customers, government, civil society consider environment as important components of the CSR. The company acts either preventive or proactive is an act of CSR.

With the growing pressure from civil society organizations and other groups, the corporate sector in Nepal is taking social responsibility seriously (Afful, 2003). For example, FNCCI has in cooperation with the UN women's organization is supporting children education. Individual companies have also been involved in development activities such as Micro hydropower projects, biogas projects, environment, health and agricultural program. However, real picture is that most corporate sector organizations are aware of the socio-economic conditions of their surrounding communities. Unfortunately, they do not respond to it unless there is pressure. The relationship between the corporate sector and communities has still not been clearly defined (Afful, 2003). Bista (2005) mentioned some extent of CSR in MNC firms in Nepal.

Observation on corporate law and policies of Nepal provides three tier legal and policy literatures such as Industrial Policy 1993, Foreign Direct Investment Act and One Window Policy 1992 and Interim Plan 2007-2010. All have mentioned CSR but not mandatory.

\section{METHODOLOGY}

\subsection{Conceptual Framework}

Corporate Social Responsibility (CSR) is inevitable ingredient of corporate governance of the corporate sector to create corporate branding value in the market and to make the consumer loyal on products. It is called corporate citizenship or responsible business. Carroll (1999) explains CSR having economic responsibility, legal compliance, ethical and philanthropy. It has three objectives: value creation, risk management and philanthropy. 
Figure 2: CSR Framework

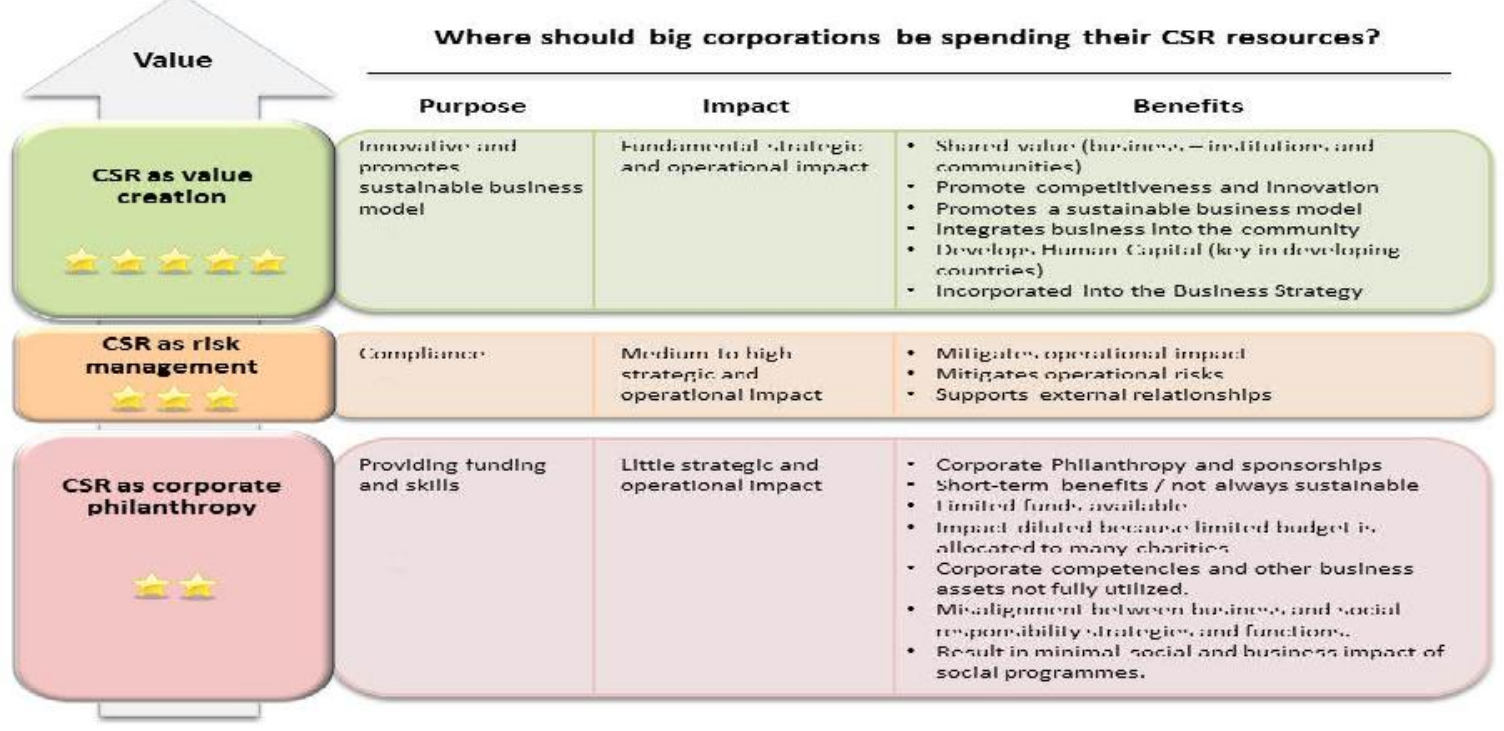

Multinational companies (MNCs) or Corporate are profit motive. Its profit function is to maximize net profit at large scale. In principle, such business should be responsible. It means the corporate should be responsible to the society. Then, the corporate business will be sustainable with value and good response. In order to make responsible business, the certain percentage of profit is spent to the society. Therefore, CSR depends on the corporate governance and profit. After creating value, CSR has positive impacts on sales growth and profit. Therefore, profit depends on CSR.

Figure 3: Conceptual Framework of CSR

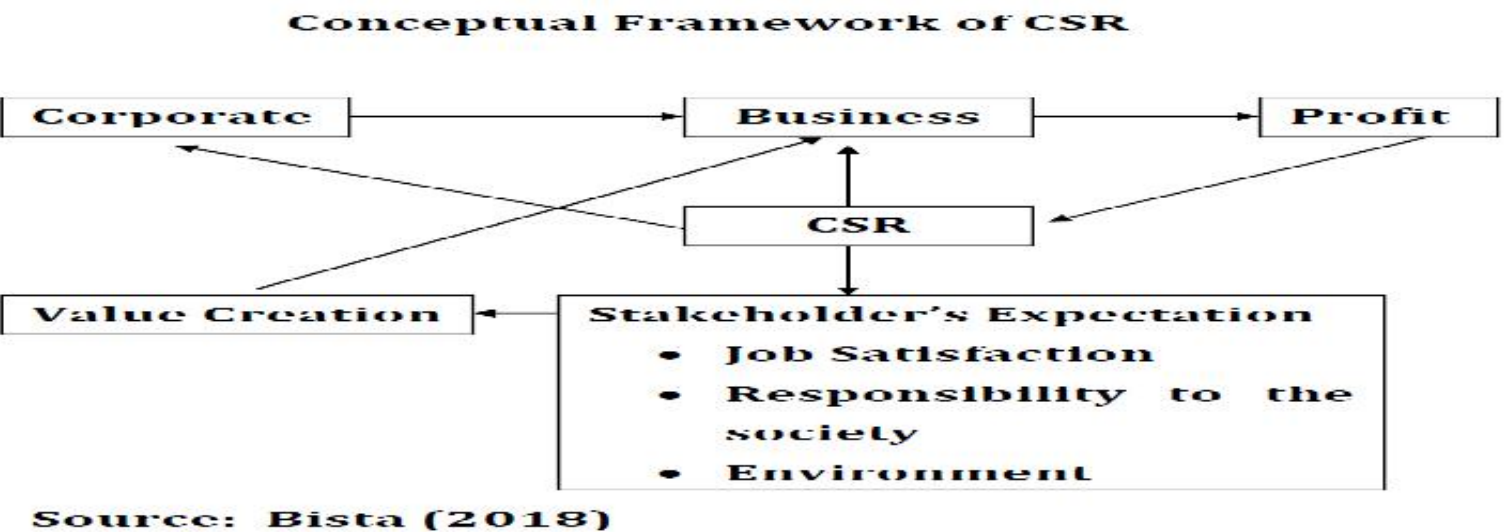

\subsection{Data Sets and Data Collection Method}

Responding above these objectives stated in this paper, we employed explorative and descriptive research method. Data sources of the paper was primarily secondary data and 
information collected from the published documents of the commercial banks, particularly their published audit report from 2008 to 2017. Out of total commercial banks (28), we selected six commercial banks by using purposive methods. The selected commercial banks included three different banks: joint venture banks (NABIL), private banks (Nepal Investment Bank, Mega Bank, Siddhartha Bank and Civil Bank) and public banks (Nepal Bank Limited). All public Banks provide their services to all 75 districts and almost villages. The joint venture and private Banks have covered only 70 percent districts, except Himalayan districts.

As supplementary, the primary data about CSR perception of stakeholders was collected at two levels: 60 staffs of the Banks at first stage and 100 stakeholders at second stage. The first level information was collected through telephone interview method. The second level information was collected through structure questionnaire survey in Kathmandu.

\section{RESULTS AND DISCUSSION}

\subsection{CSR Characteristics}

CSR of the Commercial Banks is inevitable to their corporate governance and corporate development. The Commercial Banks have conducted CSR at some extent in the country for a long time. For their value creation and social relationship, these activities are important events. At academic and business level, these activities are concern in the context of International norms, values and system of Multinational Company and Social Development Goal (SDG). In this context, there is a query about their CSR characteristics for understanding CSR activities, status, pattern, size and institution. In order to capture the CSR characteristics, the study has employed eight indicators: No of Years for CSR, Regularity in some years, CSR size, percentage of profit, CSR team, CSR events, CSR disclosure and the year of establishment.

Out of 28 Commercial Banks, the sample Banks are well established with commercial good will in the financial market. There are three banks before the Structural Adjustment Program (SAP) 1990: Nepal Bank (1937), NABIL (1984) and Nepal Investment Bank (1986). Nepal Bank was established in Rana Regime; meanwhile NABIL and Nepal Investment Bank were immediate after Structural Adjustment Program (SAP) 1980. The remaining three banks were established after the SAP II: Mega Bank (2010), Siddartha Bank (2002) and Civil Bank (1993). When we talk about the age of the Commercial Banks, their age are 81 years age of Nepal 
Bank, 34 years age of NABIL, 32 years age of Nepal Investment Bank, 25 years age of Civil Bank, 18 years age of Mega Bank and 16 years age of Siddhartha Bank. Based on CSR disclosure, these banks have given least years for CSR activities. Out of 81 years age, Nepal Bank has given a year for CSR. It is 1.23 percent year. Similarly, when we observe CSR activities, there are 5 years of NABIL(14\%), 4 years of Mega Bank(22\%), 3 years of Nepal Investment Bank(9\%), 2 years of Siddartha Bank(12.5\%) and 1 years of Civil Bank(4\%). Thus, the Commercial Banks have allocated their time for CSR activities. It indicates CSR at least priority in the Commercial Banks.

When we observe Multinational Company like Microsoft, Google, MacDonald, Apple, etc., CSR activities are regular and consistently continuous, like as their operational activities so that the Corporate has positive impact not only at the society but also at business community and at the government. Its indirect effect will fall on the business promotion and then on the sales growth and customer's growth. Based on CSR disclosure of the Commercial Bank, CSR activities have irregular and discontinuous pattern since their establishment years. However, when they have initiated CSR activities, CSR is regular and continuous at some extents in four banks: NABIL, Nepal Investment Bank, Mega Bank and Siddartha Bank. However, it is not in Civil Bank and Nepal Bank.

In general, the corporate sector forms CSR team as international practices for whole year CSR activities. In the sample Commercial Banks, there is not such team for CSR activities. It also indicates the least priority of the Commercial Bank on CSR activities and no mandatory of CSR. Its reflection can be found in CSR size and Percentage of Profit. In general, the Commercial Banks have at least double-digit billion Rupees profit per annum. However, their sacrifice for CSR to social cause and value creation negligible that is 0.05 percent. Thus, the Commercial Banks have negligible size and share of profit on CSR. In other words, it is ignorance of the Commercial Bank to their social responsibility. 
Table 1: CSR characteristics of the Commercial Banks

\begin{tabular}{|l|c|c|c|c|c|c|}
\hline & NABIL & $\begin{array}{l}\text { Nepal } \\
\text { Investment } \\
\text { Bank }\end{array}$ & $\begin{array}{l}\text { Mega } \\
\text { Bank }\end{array}$ & $\begin{array}{l}\text { Siddartha } \\
\text { Bank }\end{array}$ & $\begin{array}{l}\text { Civil } \\
\text { Bank }\end{array}$ & $\begin{array}{l}\text { Nepal } \\
\text { Bank }\end{array}$ \\
\hline No of Years for CSR & 5 & 3 & 4 & 2 & 1 & 1 \\
\hline $\begin{array}{l}\text { Regularity in some } \\
\text { years }\end{array}$ & yes & yes & yes & yes & no & no \\
\hline CSR Size & $41,43,094$ & $38,04,000$ & 0 & 610,000 & 60,000 & $53,00,000$ \\
\hline$\%$ of Profit & 0.04 & 0.14 & 0 & 0 & 0.013 & 0.18 \\
\hline CSR team & No & No & No & No & No & No \\
\hline CSR events(Mean) & 5 & 12 & 4 & 6 & 2 & 1 \\
\hline CSR disclosure & yes & yes & yes & yes & yes & yes \\
\hline Establishment Year & 1984 & 1986 & 2010 & 2002 & 1993 & 1937 \\
\hline
\end{tabular}

Source: Audit Report of the commercial Banks, 2008-2017 and Official Websites of the Banks

\subsection{CSR Trends of the Commercial Banks}

CSR of the corporate is must. Literatures argue the corporate having social responsibility to the society because of ethical business as well as value creation of business. In USA and Europe countries, its trend is positively inclining. It has a good impact on the society and the sales of the corporate. How much the Commercial Banks have practiced CSR since their establishment is concerned to understand the Commercial Bank's level of ethical business. Based CSR disclosure of the Commercial Banks, CSR trend is irregular and discontinuous over nine year's data. NABIL bank has six years trend with the fluctuation. Nepal Investment Bank has also 3 years trend meanwhile other remaining Commercial Banks ( Mega Bank, Siddartha Bank, Civil Bank and Nepal Bank) has not trend. When we observe the awareness and understanding level about CSR nationally and internationally, its trend line is positively inclining. However, in the Commercial Banks, its trend line is erratic and unpredictable. Its impact is negative.

Table 2: CSR Trends of the Commercial Banks

\begin{tabular}{|l|c|c|c|c|c|c|}
\hline Year & $\begin{array}{c}\text { NABIL } \\
(\mathrm{Rs})\end{array}$ & $\begin{array}{c}\text { Nepal Investment } \\
\text { Bank } \\
(\mathrm{Rs})\end{array}$ & $\begin{array}{c}\text { Mega Bank } \\
(\mathrm{Rs})\end{array}$ & $\begin{array}{c}\text { Siddartha } \\
\text { Bank } \\
(\mathrm{Rs})\end{array}$ & $\begin{array}{c}\text { Civil } \\
\text { Bank } \\
(\mathrm{Rs})\end{array}$ & $\begin{array}{c}\text { Nepal } \\
\text { Bank } \\
(\mathrm{Rs})\end{array}$ \\
\hline 2008 & 0 & $28,35,000$ & 0 & 0 & 0 & 0 \\
\hline 2009 & 0 & $80,00,000$ & 0 & 0 & 0 & 0 \\
\hline 2010 & 0 & 577,000 & 0 & 0 & 0 & 0 \\
\hline 2011 & 0 & 0 & 0 & 0 & 0 & 0 \\
\hline 2012 & 115,000 & 0 & 0 & 0 & 0 & 0 \\
\hline 2013 & 420,000 & 0 & 0 & 0 & 0 & 0 \\
\hline 2014 & $24,25,000$ & 0 & 0 & 0 & 0 & 0 \\
\hline 2015 & $201,30,000$ & 0 & 0 & 0 & 0 & 0 \\
\hline
\end{tabular}




\begin{tabular}{|l|c|c|c|c|c|c|}
2016 & 250,000 & 0 & 0 & 0 & 0 & $53,00,000$ \\
\hline 2017 & $11,16,783$ & 0 & 0 & 610,000 & 120,000 & 0 \\
\hline
\end{tabular}

Source: Audit Report of the commercial Banks, 2008-2017 and Official Websites of the Banks

\subsection{CSR Pyramids}

CSR Pyramids has four major components: value creation, philanthropy, legal provision and ethical responsibility. In developed countries, they have practiced all components as social responsibility of their corporate business. In the least CSR size and its irregular practices, there is concern about CSR Pyramids to understand the structure and composition of CSR.

Whatever the Commercial Banks have conducted CSR activities, almost all the Commercial Banks have given first priority on philanthropy. NABIL and Nepal Investment Bank have given priority on value creation. Except philanthropy and value creation, the Commercial Banks have not given priority as ethical and legal compliances. Out of total CSR activities, the commercial Banks have given 25 percent priority on philanthropy and 12 percent on value creation. Thus, CSR activities have not followed international practices of CSR.

Table 3: CSR Pyramids of the Commercial Banks

\begin{tabular}{|l|c|c|c|c|c|c|}
\hline CSR Pyramids & NABIL & $\begin{array}{c}\text { Nepal } \\
\text { Investment } \\
\text { Bank }\end{array}$ & $\begin{array}{c}\text { Mega } \\
\text { Bank }\end{array}$ & $\begin{array}{c}\text { Siddartha } \\
\text { Bank }\end{array}$ & $\begin{array}{c}\text { Civil } \\
\text { Bank }\end{array}$ & $\begin{array}{c}\text { Nepal } \\
\text { Bank }\end{array}$ \\
\hline Ethical responsibility & 0 & 0 & 0 & 0 & 0 & 0 \\
\hline Legal provision & 0 & 0 & 0 & 0 & 0 & 0 \\
\hline Philanthropy & 1 & 1 & 1 & 1 & 1 & 1 \\
\hline Value creation & 1 & 1 & 0 & 0 & 0 & 0 \\
\hline
\end{tabular}

Source: Audit Report of the commercial Banks, 2008-2017 and Official Websites of the Banks

\subsection{CSR size of the so claimed CSR Bank, NABIL}

This is case of NABIL. The selection of NABIL is due to the so claimed CSR first Bank and the CSR disclosure. Despite voluntarily nature of CSR, there is a query about CSR size in the percentage of NABIL's Profit. When we observe nine years' time series data of CSR and Profit of NABIL from 2008 to 2017, NABIL has maintained 2.12 billion mean profit. However, its mean CSR is approximately 0.11 percentage sacrifice of the profit. It is very least. Because of it's voluntarily and non-ethical practices, whatever size of CSR is impressive. When we observe other Commercial Banks, their situation is worse more than the CSR first bank, NABIL. It indicates no schooling and behavior of the corporate to CSR. 
Table 4: CSR size of the so claimed first CSR Bank, NABIL

\begin{tabular}{|l|c|c|c|}
\hline Year & CSR (Rs) & $\begin{array}{c}\text { Profit(Rs in } \\
\text { Billion }\end{array}$ & $\begin{array}{c}\% \text { CSR of } \\
\text { Profit }\end{array}$ \\
\hline 2008 & 0 & 1.55 & 0.00 \\
\hline 2009 & 0 & 1.63 & 0.00 \\
\hline 2010 & 0 & 1.14 & 0.00 \\
\hline 2011 & 0 & 1.34 & 0.00 \\
\hline 2012 & 115,000 & 1.70 & 0.01 \\
\hline 2013 & 420,000 & 2.22 & 0.02 \\
\hline 2014 & 2425,000 & 2.33 & 0.10 \\
\hline 2015 & $201,30,000$ & 2.10 & 0.96 \\
\hline 2016 & 250,000 & 3.62 & 0.01 \\
\hline 2017 & $11,16,783$ & 3.62 & 0.03 \\
\hline
\end{tabular}

Source: Audit Report of the commercial Banks, 2008-2017 and Official Websites of the Banks

If we observe CSR and Profit of NABIL from 2012 to 2017, we can get positive correlation between CSR and Profit. However, if we observe negligible CSR portion of profit, its impact can be found to create value creation and business promotion of NABIL in terms of the growth of profit. Thus, CSR is valuable multiplier of profit of NABIL.

\subsection{CSR provision}

CSR provision is must. In USA, European countries and India, it is mandatory to sacrifice at least 2 percentage of the corporate profit. In 2017, Microsoft company made 8 billion US\$ profit, out of which the company raised 1 billion US\$ CSR fund. It is nearly 12.5 percent of the company's profit. It is not mandatory but also ethical and value creation activities. Microsoft is motivated with the positive impact on sales and profit. In Nepal, it is voluntarily. Therefore, its impact and compliance are ineffective.

In the Commercial Banks, there is small telephone survey about CSR provision to 60 professionals. Almost all respondents have given voluntarily as reason behind small size of CSR. In addition, they hope that CSR will increase, if the provision is made mandatorily. Therefore, almost all focus on the need of CSR mandatory in the corporate law. 
Table 5: CSR provision

\begin{tabular}{|l|c|c|c|c|c|c|}
\hline CSR provision & NABIL & $\begin{array}{c}\text { Nepal } \\
\text { Investment } \\
\text { Bank }\end{array}$ & $\begin{array}{c}\text { Mega } \\
\text { Bank }\end{array}$ & $\begin{array}{c}\text { Siddartha } \\
\text { Bank }\end{array}$ & $\begin{array}{c}\text { Civil } \\
\text { Bank }\end{array}$ & $\begin{array}{c}\text { Nepal } \\
\text { Bank }\end{array}$ \\
\hline Mandatory & 0 & 0 & 0 & 0 & 0 & 0 \\
\hline Voluntarily & 100 & 100 & 100 & 100 & 100 & 100 \\
\hline Need to Mandatory & 100 & 100 & 100 & 100 & 100 & 100 \\
\hline
\end{tabular}

Source: Field Survey, 2018

\subsection{CSR survey with Stakeholders}

In the study, CSR survey with Stakeholders provides the stakeholder's perception about CSR situation, level, need and suggestion. The CSR survey with Stakeholders was conducted at small scale (100 respondents) in above sample banks to just understand the stakeholder's perception, understanding, satisfaction level and suggestion. The respondents were five categorical people: politician, professional, business, general customer and general people.

CSR knowledge is important to stakeholders to make effective CSR activities. If we assume all stakeholders have information and knowledge about CSR, it will be wrong. In the survey, except politicians, professionals and business people, general customer and general people have least knowledge about CSR (see its details in Table 6). May be it is due to the poor, small and irregular CSR of the Commercial Banks. Table 6 shows that except General Customer and General people, the politicians, professional and business people have some extent of knowledge about CSR activities of the Commercial Bank. However, most of all respondents have not information about CSR activities of the Commercial Bank, although most respondents of politicians, professionals and business people have acknowledged that they are CSR stakeholders.

As stakeholders, they should have higher satisfaction level. Table 6 shows their poor satisfaction level. Almost all stakeholders have opined need of CSR and Banks should conduct CSR. Therefore, small CSR of the Commercial Banks is still insufficient to make good impression to the stakeholders. 
Table 6: CSR survey with Stakeholders

\begin{tabular}{|c|c|c|c|c|c|c|c|c|c|c|c|}
\hline \multirow[b]{2}{*}{ Respondents } & \multicolumn{2}{|c|}{$\begin{array}{l}\text { Knowledge } \\
\text { about CSR }\end{array}$} & \multicolumn{2}{|c|}{$\begin{array}{c}\text { CSR } \\
\text { activities of } \\
\text { the } \\
\text { commercial } \\
\text { bank }\end{array}$} & \multirow[b]{2}{*}{$\begin{array}{l}\text { if yes, its } \\
\text { frequency }\end{array}$} & \multicolumn{2}{|c|}{$\begin{array}{c}\text { Are you } \\
\text { stakeholder } \\
\text { in CSR }\end{array}$} & \multicolumn{2}{|c|}{$\begin{array}{c}\text { your } \\
\text { satisfaction } \\
\text { level }\end{array}$} & \multicolumn{2}{|c|}{$\begin{array}{l}\text { should the } \\
\text { Bank } \\
\text { conduct } \\
\text { CSR }\end{array}$} \\
\hline & $\begin{array}{l}\text { Yes } \\
(\%)\end{array}$ & $\begin{array}{l}\text { No } \\
(\%)\end{array}$ & $\begin{array}{l}\text { Yes } \\
(\%)\end{array}$ & $\begin{array}{l}\text { No } \\
(\%)\end{array}$ & & $\begin{array}{l}\text { Yes } \\
(\%)\end{array}$ & $\begin{array}{l}\text { No } \\
(\%)\end{array}$ & $\begin{array}{c}\text { Good } \\
(\%)\end{array}$ & $\begin{array}{c}\text { Poor } \\
(\%)\end{array}$ & $\begin{array}{l}\text { Yes } \\
(\%)\end{array}$ & $\begin{array}{l}\text { No } \\
(\%)\end{array}$ \\
\hline Politicians & 70 & 30 & 30 & 70 & 1 & 60 & 40 & 30 & 70 & 100 & \\
\hline Professional & 90 & 10 & 50 & 50 & 2 & 80 & 20 & 20 & 80 & 100 & \\
\hline $\begin{array}{l}\text { Business } \\
\text { people }\end{array}$ & 60 & 40 & 30 & 70 & 3 & 70 & 30 & 25 & 75 & 100 & \\
\hline $\begin{array}{l}\text { General } \\
\text { Customer }\end{array}$ & 20 & 80 & & 100 & 0 & 40 & 60 & & 100 & 100 & \\
\hline $\begin{array}{l}\text { General } \\
\text { People }\end{array}$ & 5 & 95 & & 100 & 0 & & 100 & & 100 & 100 & \\
\hline
\end{tabular}

Source: Field Survey, 2018

\section{CONCLUSION}

Despite the strong commitment of FNCCI on effective CSR and business ethics in different public programs and voluntary obligation of CSR in Law and Policy, reality of almost the Commercial Banks is very gloomy and contradicted with the so-called practice of CSR because the practice of CSR is very irregular, voluntary, small and poor. Therefore, its outcomes cannot be accounted at significant level in social interest and business promotion. However, they have positive impact on the community for improving the relationship between the corporate sector and the community. Therefore, the government should make effective policy measures related to CSR, like as Europe and USA so that the corporate sector can sacrifice their profit regularly and uniformly in accordance with the CSR provision of Law and Policy. Then, the country will get significant benefit in the side of skill transformation, social security, community development and environment protection. Otherwise, the Commercial Banks will be a hot issue in future for the community and the civil society conducting movement for CSR.

\section{REFERENCE}

Afful, K (2003). "Corporate Social Responsibility”. Organization. July September, Kathmandu:ODC

Berle A. A. Jr (1932). "For whom corporate managers are trustees: A note". Harvard Law Review. USA: Harvard School of Law 45(8):1365-72. 
Bista, R.B. (2004). Foreign Direct Investment in Nepal: Regression analysis in aspect of GDP growth and export, Economics Journal of Development Issues, 5(2):93-110.

Bista, R.B. (2005). Foreign Direct Investment in Nepal. Kathmandu: Center for Integrated Development Studies

Bista, R.B. (2005). 'Direction and effectiveness of trade policy reform: A case study of IndoNepal trade development'. Economic Journal of Development Issues, 6(2): 26-35.

Bista, R.B. (2008). Economics of Nepal. Kathmandu: Prativa Publication

Bista, R.B. (2009). 'Liberalization and Productivity Growth in Nepal: A case of FDI firm', published in

www.iioa.org/conferences/18th/papers/files/90_20091229030_ProductivitGrowthofFDIfirm.pdf Vienna,Austria

Bista, R.B. (2011). Economics of Nepal. Kathmandu: New Hira Books

Bista, R.B. (2011). BIPPA and Foreign Direct Investment in Nepalese Economy: A policy analysis, Artha Journal, 31(1):1-5

Bista, R.B. (2011) FDI and Corporate Social Responsibility: A Developing Country Case Study of Nepal in Corporate Social Responsibility: Critiques, Policies and Strategies edited by Prasenjit Maiti, Sharda Publishing House: Jodhpur India.

Bista, R.B. (2016). Economics of Nepal. Kathmandu: New Hira Books

Borok, T. (2003). "A modern approach to redefining in the best interests of the corporation". Windsor Review of Legal and Social Issues 15(4):113.

Carmeli, A. (2005). Perceived external prestige, affective commitment, and citizenship behaviors. Organization Studies, 26: 443-464.

Carroll, A. B. (1999). Corporate social responsibility. Business \& Society, 38: 268-295.

Choper, Coffee, Gilson (2004). Cases and materials on corporations. 6th ed. London: Little, Brown \& Co.

Corfield, A. (1998). "The stakeholder theory and its future in Australian corporate governance: A preliminary analysis". Bond Law Review, 10(2):213.

Dodd E. M Jr(1932). "For whom are corporate managers trustees?" Harvard Law Review 45(7):1145-63.

Donohue, J. (2005) "Does greater managerial freedom to sacrifice profits lead to higher social welfare?" In Environmental Protection and the Social Responsibility of Firms-Hay Bruce, Stavins Robert, Vietor Richard, eds. Washington, DC: Resources for the Future.

Elhauge, E(2005). "Corporate managers' operational discretion to sacrifice corporate profits in the public interest". In: Environmental Protection and the Social Responsibility of Firms-Bruce Hay, Stavins Robert, Vietor Richard, eds. Washington, DC: Resources for the Future. 
Fanto, J. A(1998). "The role of corporate law in French corporate governance". Cornell International Law Journal 31:31.

FNCCI (2006). CSR Report, Seminar on Business Ethics and Corporate Social Responsibility, Kathmandu: FNCCI

Government of India (GoI)(2017). The Corporate Law. New Delhi: Ministry of Law

Government of Nepal (GoN)(2017). The Corporate Law. Kathmandu: Ministry of Law

Graff, Z., Joshua, Small, A. (2005). “A Modigliani-Miller theory of altruistic corporate social responsibility". B. E. Journals in Economic Analysis and Policy: Topics in Economic Analysis and Policy 5(1):1-19.

Griffin R.W.(1998). Management $5^{\text {th }}$ edition New Delhi:A.I.T.B.S

Lynch-Fannon, I. (2007). "The corporate social responsibility movement and law's empire: Is there a conflict?" Northern Ireland Legal Quarterly 58(1).

Marinov, B and Heiman, B. (1998). "Company law and corporate governance renewal in transition economies: The Bulgarian dilemma”. European Journal of Law and Economics 6:231-61

Ministry of Finance (MoF)(2017) Economic Survey. Kathmandu: MoF

Miwa, Y.(1999). "CSR: Dangerous and harmful, though maybe not irrelevant". Cornell Law Review 84(July):1227-54.

Nepal Rastriya Bank(NRB) (2017). Statistics of the Commercial Banks. Kathmandu: NRB

Portney, P.(2005). "Corporate social responsibility: An economic and public policy perspective". In: Environmental Protection and the Social Responsibility of Firms-Hay Bruce, Stavins Robert, Vietor Richard, eds. Washington, DC: Resources for the Future

Reinhardt, F.(2005). "Environmental protection and the social responsibility of firms: Perspectives from the business literature." In: Environmental Protection and the Social Responsibility of Firms-Hay Bruce, Stavins Robert, Vietor Richard, eds. Washington, DC: Resources for the Future.

Reputation Institute (2017). CSR Ranking Report. USA: Reputation Institute

Roe, M. (2000). "Political preconditions to separating ownership from corporate control". Stanford Law Review 53(December):539

Sen, S, Bhattaracharya, C.B and Korschun, D(2006). "The Role of Corporate Social Responsibility in Strengthening Multiple Stakeholder Relationships: A Field Experiment", Journal of the Academy of Marketing Science, 34(2): 158-166

Sriram, V and Allen, A.(2003). "A Proposal for Rethinking Corporate Social Responsibility" in Organization. July September, Kathmandu:ODC

Sutton, M(2004). "Between a rock and a judicial hard place: Corporate social responsibility reporting and potential legal liability under kasky v. nike". University of Missouri-Kansas City School of Law Review 72(Summer):1159. 